\title{
$\alpha$-1-Antichymotrypsin Promotes $\beta$-Sheet Amyloid Plaque Deposition in a Transgenic Mouse Model of Alzheimer's Disease
}

\author{
Lars N. G. Nilsson, ${ }^{1,2,3}$ Kelly R. Bales, ${ }^{5}$ Giovanni DiCarlo,, ${ }^{4}$ Marcia N. Gordon, ${ }^{4}$ Dave Morgan, ${ }^{4}$ \\ Steven M. Paul, ${ }^{5}$ and Huntington Potter ${ }^{1,2,3}$ \\ ${ }^{1}$ Suncoast Gerontology Center, ${ }^{2}$ Department of Biochemistry and Molecular Biology, ${ }^{3}$ Moffitt Cancer Center, and \\ ${ }^{4}$ Department of Pharmacology, College of Medicine, University of South Florida, Tampa, Florida 33612, and \\ 5Neuroscience Discovery Research, Lilly Research Laboratories, Indianapolis, Indiana 46285
}

$\alpha_{1}$-Antichymotrypsin (ACT), an acute-phase inflammatory protein, is an integral component of the amyloid deposits in Alzheimer's disease (AD) and has been shown to catalyze amyloid $\beta$-peptide polymerization in vitro. We have investigated the impact of ACT on amyloid deposition in vivo by generating transgenic GFAP-ACT-expressing mice and crossing them with the PDGF-hAPP/N717F mice, which deposit amyloid in an agedependent manner. The number of amyloid deposits measured by Congo Red birefringence was increased in the double ACT/ amyloid precursor protein (APP) transgenic mice compared with transgenic mice that only expressed APP, particularly in the hippocampus where ACT expression was highest, and the increase was preceded by elevated total amyloid $\beta$-peptide levels at an early age. Our data demonstrate that ACT promotes amyloid deposition and provide a specific mechanism by which inflammation and the subsequent upregulation of astrocytic $\mathrm{ACT}$ expression in $\mathrm{AD}$ brain contributes to $\mathrm{AD}$ pathogenesis.

Key words: $\alpha 1$-antichymotrypsin; Alzheimer's disease; amyloid deposition; inflammation; transgenic mice; amyloid $\beta$-peptide; Congo Red
$\alpha_{1}$-Antichymotrypsin (ACT), an acute-phase inflammatory protein, has been found to be an integral component of the amyloid core filaments of Alzheimer's disease (AD) brain and to be overexpressed in astrocytes surrounding amyloid plaques (Abraham et al., 1988; Pasternack et al., 1989; Koo et al., 1991). ACT has been shown to be only associated with amyloid deposits containing amyloid $\beta$-peptides $(\mathrm{A} \beta)$,suggesting the presence of a specific molecular interaction between ACT and AD plaque components, likely the amyloid $\beta$-peptides themselves (Abraham et al., 1990). This idea has been further reinforced by in vitro experiments showing high-affinity binding of ACT to amyloid $\beta$-peptides (Potter et al., 1992; Fraser et al., 1993; Hughes et al., 1998). The term "pathological chaperone" has been coined to describe amyloid-associated proteins, such as ACT or apolipoprotein $\mathrm{E}$ (ApoE), that have the potential ability to favor conformational transition of $\mathrm{A} \beta$ peptides into a $\beta$-pleated sheet structure and thereby promote their deposition into senile plaques (Wisniewski and Frangione, 1992).

In vitro studies have demonstrated that $\mathrm{ACT}$ and ApoE promote the assembly of the $\mathrm{A} \beta_{1-42}$ peptide into amyloid filaments (Ma et al., 1994, 1996; Sanan et al., 1994; Wisniewski et al., 1994; Janciauskiene et al., 1996, 1998). However, using the $\mathrm{A} \beta_{1-40}$ peptide or an equimolar ratio, ApoE and ACT have also been

\footnotetext{
Received Oct. 2, 2000; revised Nov. 27, 2000; accepted Dec. 15, 2000.

The research was supported by National Institutes of Health Grant AG09665 to H.P. L.N.G.N. is presently supported by a fellowship from the John Douglas French Alzheimer's Foundation and previously by the Stiftelsen für Internationalisering au högre utbildning och forskning foundation and Riksbankens Jubileumsfond (after a donation from Erik Rönnberg). H.P. occupies the Eric Pfeiffer Chair for Research in Alzheimer's disease at the Suncoast Gerontology Center at the University of South Florida.

Correspondence should be addressed to Dr. Huntington Potter or Dr. Lars Nilsson, Department of Biochemistry and Molecular Biology, College of Medicine, MDC07, University of South Florida, Tampa, FL 33612. E-mail: hpotter@ hsc.usf.edu and lnilsson@hsc.usf.edu.

Copyright (C) 2001 Society for Neuroscience $\quad 0270-6474 / 01 / 211444-08 \$ 15.00 / 0$
}

reported to inhibit $\mathrm{A} \beta$ filament formation (Fraser et al., 1993; Eriksson et al., 1995; Evans et al., 1995). Although the epidemiological evidence and their overexpression in AD brain suggest that ACT and ApoE are more likely to be amyloid promoters, in vivo experiments would greatly aid in clarifying their pathophysiological role.

Recent studies have supported the hypothesis that ApoE is a pathological chaperone. The frequency of thioflavine S-positive $\mathrm{A} \beta$ deposits in the human amyloid precursor protein (hAPP)/ $\mathrm{V} 717 \mathrm{~F}$ overexpressing transgenic mouse strain has been found to be ApoE gene dose-dependent, and no such deposition occurs in the absence of the murine ApoE (Bales et al., 1997). Furthermore, human ApoE4 has been shown to restore thioflavine S-positive $\mathrm{A} \beta$ deposition and neuritic plaque formation at an accelerated rate compared with human ApoE3 (Holzman et al., 2000), reflecting the epidemiological data on neuritic plaque formation in AD brain (Rebeck et al., 1993; Schmechel et al., 1993).

A similar set of in vivo experiments should clarify the role of ACT in amyloid formation. Unfortunately, the knock-out approach is not possible, because mice lack an ACT homolog with respect to its $\mathrm{A} \beta$ peptide interacting ability. The human ACT gene shares the highest sequence homology with the family of murine Spi-2 protease inhibitors (Inglis and Hill, 1991). However, the reactive center loop of these protease inhibitors, which is the likely $\mathrm{A} \beta$ peptide interacting region in the human ACT protein (Potter et al., 1992; Janciauskiene et al., 1996, 1998), is hypervariable and differs substantially from that of the human ACT protein (Hill and Hastie, 1987). Here we report on a new transgenic mouse and on experiments pursued to determine the function of ACT as an amyloid promoter in vivo.

\section{MATERIALS AND METHODS}

Construction of transgenic mice. A cDNA fusion construct with a $6 \mathrm{kbp}$ mouse glial fibrillary acidic protein (GFAP) promoter and $100 \mathrm{bp}$ of the 
5 '-end of the GFAP gene attached to the human ACT cDNA clone was constructed to direct human ACT synthesis in activated mouse astrocytes. The unique ApaI-SalI fragment $(-107$ to +87$)$ in the GFAPsecreted alkaline phosphatase expression vector (Sarid, 1991) was subcloned into the Litmus-38 vector, and the two existing ATG start codons in the GFAP transcript were altered to ATC and AGG, respectively, with PCR-based site-directed mutagenesis. The original ApaI-SalI fragment was then replaced with the mutant fragment. A $1.5 \mathrm{kbp}$ full-length human ACT cDNA clone was excised with EcoRI from the pGEM4 vector (Abraham et al., 1988) and blunt-ended. SalI linkers were attached, and the fragment was subcloned into the modified GFAP expression vector construct. The noncoding $3^{\prime}$-untranslated region of the mRNA was derived from the rat preproinsulin II gene, which provided a $3^{\prime}$ intronic region and a polyadenylation [poly(A)] site. The final construct was sequenced to confirm that translation initiation should occur solely at the start codon in the ACT cDNA. The DNA was linearized with EcoRV and $S c a \mathrm{I}$, and the $10 \mathrm{kbp}$ fragment was separated on a low melting point agarose gel, purified with $\beta$-agarase according to manufacturer's instructions (FMC Bioproducts, Rockland, ME), and injected into pronuclei of $\mathrm{FVB} / \mathrm{N}$ zygotes at the Core Transgenic Mouse Facility (Brigham and Women's Hospital, Harvard Medical School, Boston, MA). Injected zygotes were transferred to pseudopregnant females. Heterozygous ACT-transgenic mice were identified with two PCR primer pairs located in different parts of the construct. Mice from one of these founder lines (\#8784) were crossed with homozygous PDGF-hAPP/V717F mice (Games et al., 1995), and all offspring were screened with PCR for the GFAP-ACT and the PDGF-hAPP gene constructs. In addition, the presence of proper ACT protein expression in astrocytes of the PDGF-hAPP/V717F $(+/-)$ ACT $(+/-)$ mice and its absence in the PDGF-hAPP/V717F (+/-)ACT (-/-) mice was verified by ACT immunohistochemistry in all of the pathologically examined animals.

Northern blot. Total RNA was extracted with RNA Stat-60-kit (Tel-Test), and poly $\left(\mathrm{A}^{+}\right)$mRNA was selected with Dynabeads Oligo(dt) ${ }_{25}$ (Dynal, Great Neck, NY). The RNA samples were heat-denatured $\left(70^{\circ} \mathrm{C}\right)$ in $50 \%$ formamide, $2.2 \mathrm{M}$ formaldehyde, $1 \mathrm{~m}$ 4-morpholinepropanesulfonic acid buffer, $\mathrm{pH} \mathrm{7.0,} \mathrm{and} \mathrm{separated} \mathrm{by} \mathrm{electrophoresis} \mathrm{on} \mathrm{a} 1.0 \%$ agaroseformaldehyde gel, blotted onto Hybond- $\mathrm{N}^{+}$filters, and baked for $2 \mathrm{hr}$ at $80^{\circ} \mathrm{C}$. Filters were prehybridized overnight and hybridized with $\mathrm{P}^{32}$-labeled hACT and hGAPDH-cRNA probes (Rogers et al., 1999) in 50\% formamide, 120 mM Tris-HCl, 8 mM EDTA, $600 \mathrm{~mm} \mathrm{NaCl}, 1 \%$ nonfat dry milk powder, and $1 \%$ SDS. The filters were subsequently washed at a stringency of $0.1 \times$ SSC, $0.1 \%$ SDS at $85^{\circ} \mathrm{C}$, and exposed to autoradiographic Hyper-MP film (Amersham Pharmacia Biotech, Arlington Heights, IL).

Immunoprecipitation and Western blot analysis. Brain tissue from a transgenic mouse was homogenized $(2 \times 10$ strokes on ice) in $10(\mathrm{v} / \mathrm{w})$ STEN/Lysis buffer (50 mM Tris, pH 7.6, $150 \mathrm{~mm} \mathrm{NaCl,} 2 \mathrm{~mm}$ EDTA, $1 \%$ NP-40, $0.2 \%$ BSA, $50 \mu \mathrm{g} / \mathrm{ml}$ PMSF, $5 \mu \mathrm{g} / \mathrm{ml}$ leupeptin, $5 \mu \mathrm{g} / \mathrm{ml}$ aprotinin, and $2 \mu \mathrm{g} / \mathrm{ml}$ pepstatin A). The homogenate was centrifuged at $50,000 \times g$ for $1 \mathrm{hr}$ at $4^{\circ} \mathrm{C}$. The supernatant was recovered, $2 \mu \mathrm{l}$ of polyclonal ACT antibody (AXL-145; Accurate Chemicals, Westbury, NY) was added, and the mixture was allowed to incubate for $2 \mathrm{hr}$ at $4^{\circ} \mathrm{C}$. We added $25 \mu \mathrm{l}$ of equilibrated protein A-Sepharose slurry (Pierce, Rockford, IL), and the mixture was allowed to incubate overnight at $4^{\circ} \mathrm{C}$. The antibody-antigen complex was retrieved by centrifugation at $15,000 \times g$ for $10 \mathrm{~min}$ and subsequently washed six times $(50 \mathrm{~mm}$ Tris-HCl, $150 \mathrm{~mm} \mathrm{NaCl}, 6 \mathrm{~mm}$ EDTA, $\mathrm{pH}$ 7.4, and 2.5\% Triton X-100) and finally twice with $50 \mathrm{~mm}$ Tris- $\mathrm{HCl}$ and $6 \mathrm{~mm}$ EDTA, $\mathrm{pH}$ 7.4. The final pellet was resuspended in $20 \mu$ l of $2 \times$ Laemmli's buffer and boiled for $10 \mathrm{~min}$, centrifuged $15,000 \times g$ for $1 \mathrm{~min}$, and the supernatant was loaded onto a $8 \%$ polyacrylamide gel (Novex). The samples were transferred to an Immobilon-P filter (Millipore, Bedford, MA), blocked with $5 \%$ nonfat dry milk powder in $1 \times$ TTBS buffer $(1 \times$ TTBS is $0.1 \mathrm{M}$ Tris-HCl, $\mathrm{pH} 7.5,0.9 \% \mathrm{NaCl}$, and $0.1 \%$ Tween 20 ), incubated with primary monoclonal ACT antibody (dilution, 1:2000; catalog \#178218; Calbiochem, La Jolla, CA) for $1 \mathrm{hr}$ at room temperature (RT) in $1 \times$ TTBS buffer, washed three times for 10 min with TTBS buffer, blocked with $5 \%$ nonfat dry milk powder in $1 \times$ TTBS, incubated with secondary goat anti-mouse antibody (dilution 1:5000; catalog \#31434; Pierce) in blocking buffer solution for $30 \mathrm{~min}$ at RT, washed four times for $10 \mathrm{~min}$ each in $1 \times$ TTBS buffer, incubated with ECL reagents (Pierce) for $5 \mathrm{~min}$, and finally exposed to ECL Hyperfilm (Amersham Pharmacia Biotech).

Histology and immunohistochemistry. Mice were anesthetized with Nembutal (1 mg/10 gm body weight) and intracardially perfused with $0.9 \% \mathrm{NaCl}(25 \mathrm{ml})$ and then with $50 \mathrm{ml} 4 \%$ paraformaldehyde in $1 \times$
Sorenson's phosphate buffer. Dissected brains were allowed to immerse in the same fixative solution overnight at $4{ }^{\circ} \mathrm{C}$ and were further cryoprotected by sequential overnight incubation in 10, 20, and $30 \%(\mathrm{w} / \mathrm{v})$ sucrose in $0.1 \times$ Sorenson's phosphate buffer. The brains were then frozen on a temperature-controlled freezing stage, coronally sectioned $(25 \mu \mathrm{m})$ on a sliding microtome, and the sections were stored in $1 \times$ PBS with $10 \mathrm{~mm} \mathrm{NaN}_{3}$ until mounted on slides. The mounted sections were preincubated with $0.3 \% \mathrm{H}_{2} \mathrm{O}_{2}$ in $50 \%$ Dako-block (catalog \# X0909; Dako, Carpinteria, CA) for 15 min to block endogenous peroxidase activity, permeabilized with $0.4 \%$ Triton X-100 in $1 \times$ PBS, pH 7.4, and incubated with Dakoblock (10 $\mathrm{min})$ to reduce nonspecific antibody staining. Primary antibodies used were rabbit anti-ACT (AXL-145; dilution 1:1000; Accurate), mouse anti-A $\beta$ (6E10; dilution 1:5000; Senetek), and mouse anti-GFAP (G-A-5; dilution 1:400; Sigma, St. Louis, MO). Tissue sections were stained with the Vectastain ABC Elite or MOM kits (Vector Laboratories, Burlingame, CA). Secondary antibodies were antirabbit IgG (BA-1000; 1:300; Vector) or anti-mouse $\operatorname{IgG}$ as provided with the kits (Vector). Incubations with primary antibodies were for $1 \mathrm{hr}$ at RT and with secondary antibodies for $30 \mathrm{~min}$ at RT. We added 50\% Dakoblock solution to the ABC reagent to lower the nonspecific signal. The immunostaining was developed with DAB $(0.4 \mathrm{mg} / \mathrm{ml}), 0.03 \% \mathrm{H}_{2} \mathrm{O}_{2}$ in $\mathrm{NiSO}_{4}$-acetate buffer, $\mathrm{pH}, 6.0\left(9 \mathrm{mg} / \mathrm{ml}\right.$ with respect to $\left.\mathrm{Ni}^{2+}\right)$, or with Vector DAB or Vector SG substrate kits. Congo Red staining was accomplished by initially hydrating the section in $\mathrm{H}_{2} \mathrm{O}$ for $30 \mathrm{~min}$, incubating in saturated alcoholic sodium chloride solution $[4 \%(\mathrm{w} / \mathrm{v})$ $\mathrm{NaCl}$ in $80 \% \mathrm{EtOH}$ ] that was alkalinized with $10 \mathrm{~mm} \mathrm{NaOH}$ (final concentration) before use. Sections were stained in a $0.2 \%$ Congo Red (Sigma) solution that had been equilibrated in saturated alcoholic sodium chloride solution by stirring overnight, filtered (Whatman1 filter), and alkalinized with $10 \mathrm{~mm} \mathrm{NaOH}$ (final concentration) before use. To induce gliosis and increase ACT expression, the same mice (3-month-old mice) were inhalation-anesthetized with Isoflurane, placed in a sterotactic instrument, and a Hamilton syringe was inserted (bregma coordinates: posterior $2.7 \mathrm{~mm}$, lateral $\pm 2.5 \mathrm{~mm}$, ventral $3 \mathrm{~mm}$ ). The animals were killed 3 d later.

Image analysis. Six equally spaced tissue sections (bregma -1.06 to $-2.30 \mathrm{~mm}$; Franklin and Paxinos, 1996) from each animal were used for the quantitative evaluations. The part of cerebral cortex examined was defined as that laterally extending to a perpendicularly drawn line from the apex of the hippocampal pyramidal cell layer in the CA3 region of the hippocampus. Hippocampal area measurement was according to regular anatomical definitions. The sections were examined in a Nikon Microphot-FX-microscope at $200 \times$ magnification at a constant predefined light setting, and video images were captured with a color CCD camera. Each Congo Red-positive amyloid plaque was circled at $200 \times$ magnification, and its location was noted onto an anatomic atlas. The captured image was segmented with respect to threshold settings for hue, saturation, and luma that had been specified before analysis to distinguish specific signals from background. The area occupied by amyloid within each circle, as defined by the image segmentation, was then quantitated. This predefined segmentation was subsequently used throughout the analysis without operator editing to determine the area of each plaque structure (Oncor). The total measurement area was quantified at $20 \times$ magnification, and the amyloid load was expressed as area fraction ( $=$ stained area $_{\text {tot }} /$ measured area $_{\text {tot }}$ ). The Congo-positive plaques counted were defined as those objects displaying gold-green bifringence under crossed polarized light and having their perimeter located outside one radius from the center of any other adjacent Congo Red-positive plaque structure. The complete plaque size distribution analysis were based on $(\sim 300$ and $\sim 175$ Congo Red-positive plaques/ brain region) in the PDGF-hAPP/V717F $(+/-) \mathrm{ACT}(+/-)$ and the PDGF-hAPP/V717F (+/-)ACT (-/-) mice, respectively.

A $\beta$ ELISA measurements. Hippocampi from 3-month-old PDGFhAPP/V717F $(+/-)$ ACT $(+/-)$ mice $(n=10)$ and PDGF hAPP/ $\operatorname{V717F}(+/-) \mathrm{ACT}(-/-)$ mice $(n=14)$ were microdissected and quickly homogenized in $5.5 \mathrm{~m}$ guanidine buffer. Homogenates were diluted 1:10 with cold casein buffer $(0.25 \%$ casein and $0.05 \%$ sodium azide $)$ followed by centrifugation for $20 \mathrm{~min}$ at $4^{\circ} \mathrm{C}$ at $10,000 \times g$. Total amyloid $\beta$-peptide $(\mathrm{A} \beta)$ and $\mathrm{A} \beta 1-42$ were measured by sandwich ELISA, as previously described (Bales et al., 1999).

Statistical analysis. The data samples collected were analyzed for deviation from Gaussian distribution using Kolgomorov-Smirnov test, and group comparison was evaluated with unpaired $t$ test. The plaque size data (in square micrometers) was logarithm transformed (with a logarithmic base of 10) and analyzed in relative frequency histograms 
Figure 1. Expression of ACT mRNA and protein in ACT transgenic mice. $a$, Immunoprecipitation and Western blot of brain protein extracts from a nontransgenic mouse and ACT-transgenic founder lines (\#8782, \#8783, and \#8784) displaying a protein band $(\sim 68$ $\mathrm{kDa})$ that closely comigrates with human serum ACT. $b$, GFAP/ACT mRNA and GAPDH mRNA expression in brain of a nontransgenic mouse and various tissues of a heterozygous ACTtransgenic mouse showing brain-specific expression of ACT only in the transgenic mouse. These experiments ( $a$ and $b)$ were performed on singly ACT transgenic animals without stab wound injury. $c$, Astrocyte expression and secretion of ACT immunoreactivity was found in the hippocampal formation of heterozygous ACT-transgenic mice $(d)$, whereas both astrocyte staining and the diffuse ACT-immunostaining in the hippocampus seen in ACT transgenic mouse was absent in nontransgenic mouse. $e$, Colocalization of ACT (brown) and GFAP (blue) immunoreactivity in astrocytes of the stab-wounded ACT $(+/-)$ mice. $f$, High-power magnification of the tissue section depicted in $c$ showing the morphology of ACT-immunopositive astrocytes. The ACT immunostaining of brain sections from both of these animals was performed $3 \mathrm{~d}$ after stab wound injury $(c-f)$. Sections were counterstained with Methyl Green $(c, d, f)$. Scale bars: $e, 7.8 \mu \mathrm{m} ; f, 12.5 \mu \mathrm{m}$.
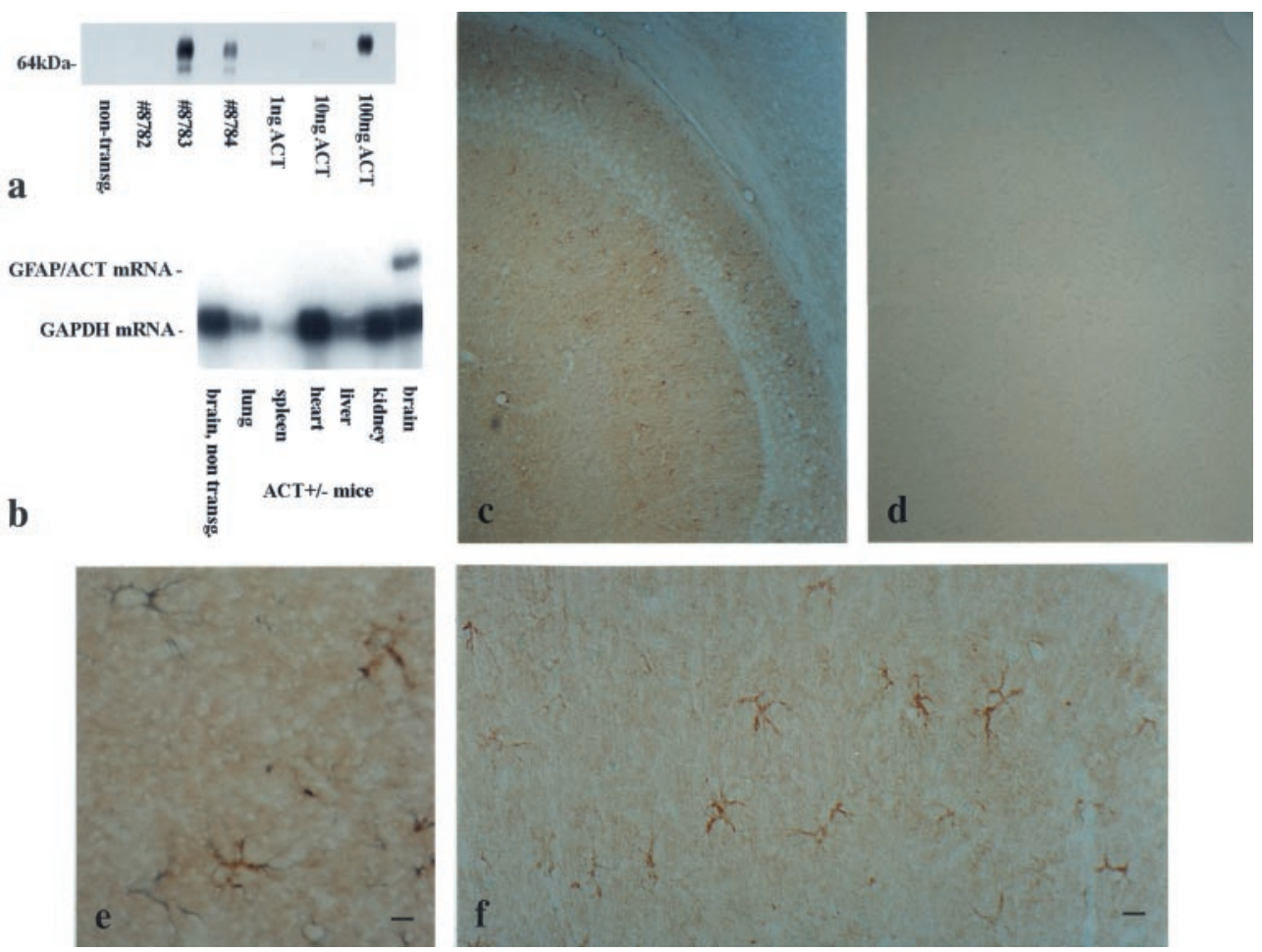

with bins of 0.2 . The logarithmic transformation was made for each individual animal separately, so that each animal would have an equal impact on the Gaussian distribution curve within its experimental group. The distribution of the population of Congo-positive plaques, with respect to plaque size, was fitted to a Gaussian distribution equation with nonlinear regression analysis (GraphPad Prism, version 2.0).

\section{RESULTS}

\section{Astrocyte-specific and inducible ACT expression in transgenic mice}

A novel transgenic mouse that synthesizes ACT in an astrocytespecific, inducible expression pattern that mimics ACT expression in the human brain was desired. To this end, we designed a novel astrocyte-specific GFAP (6 kbp) promoter construct extending $80 \mathrm{bp}$ into a modified GFAP-coding region, to allow interactions between possible gene regulatory sequences within the GFAP coding region and upstream enhancer elements (Nakatani et al., 1990). Start codons in the GFAP segment were then altered before the introduction of the ACT cDNA so that the construct directed the translation to begin at the ACT start codon. The ACT transgenic animals resulting from the embryos transfected with the GFAP-ACT construct were viable with no overt pathological signs and expressed fully glycosylated ACT protein $(\sim 68 \mathrm{kDa})$ in the brain that closely comigrated with human plasma ACT protein (Fig. 1a). Furthermore, the animals displayed a restricted expression pattern of the chimeric GFAPACT mRNA transcript that was limited to brain tissue (Fig. 1b). These experiments were all performed on GFAP-ACT transgenic mice without stab wound injury.

The animals were further investigated using stab-wound injury to demonstrate additional desired expression characteristics such as inducible synthesis of the ACT protein in $\mathrm{ACT}(+/-)$ mice (Fig. 1c,f), but not in $\operatorname{ACT}(-/-)$ mice (Fig. 1d), and astrocyte specificity (shown by double immunostaining for GFAP and ACT (Fig. 1e). Similar immunostaining of astrocyte processes has been observed after GFAP-driven expression of the secretory chaperone protein ApoE (Sun et al., 1998). The diffuse ACT immunostaining seen in the hippocampus of $\mathrm{ACT}(+/-)$ mice (Fig. 1c,f) was very faint in the cerebral cortex and completely absent in brain sections of a stab wound-injured $\mathrm{ACT}(-/-)$ sibling mouse that was processed in parallel throughout the immunostaining procedures (Fig. 1d). We suggest that the diff use ACT immunostaining likely represents secretion of ACT from astrocytes, which would be expected of a secretory acute phase protein such as ACT. The validity of the double-staining protocol was established by processing tissue sections from animals that either expressed ACT or did not express ACT in the absence of one or both of the primary ACT and GFAP antibodies and finding no labeling (data not shown).

\section{ACT in astrocytes and amyloid plaques of APP/ACT transgenic mice}

Mice from the founder line (\#8784) were crossed with homozygous PDGF-hAPP/V717F mice because this founder mouse easily transferred the transgene to its offspring ( $\sim 50 \%$; Games et al., 1995). At the earliest time point investigated (4 months of age) ACT-immunopositive astrocytes were apparent in the PDGF$\mathrm{hAPP} / \mathrm{V} 717 \mathrm{~F}(+/-) \mathrm{ACT}(+/-)$ mice in the absence of any treatment such as stab wound, and were mostly restricted to astrocytes in white matter areas such as the anterior commissure, the cingulum, and the corpus callosum and close to the ventricles. This expression pattern represented the basal expression of the ACT transgene and was identical to that of singly ACT transgenic mice and also similar to the expression of ACT in normal human brain (Abraham et al., 1988; Pasternack et al., 1989; Koo et al., 1991).

At 6 months of age, when amyloid plaques were sparsely distributed in the hippocampus, ACT-immunostained astrocytes were clearly visible along the hippocampal fissure (Fig. $2 a$ ). By 10 months, when amyloid deposition was more pronounced, the 

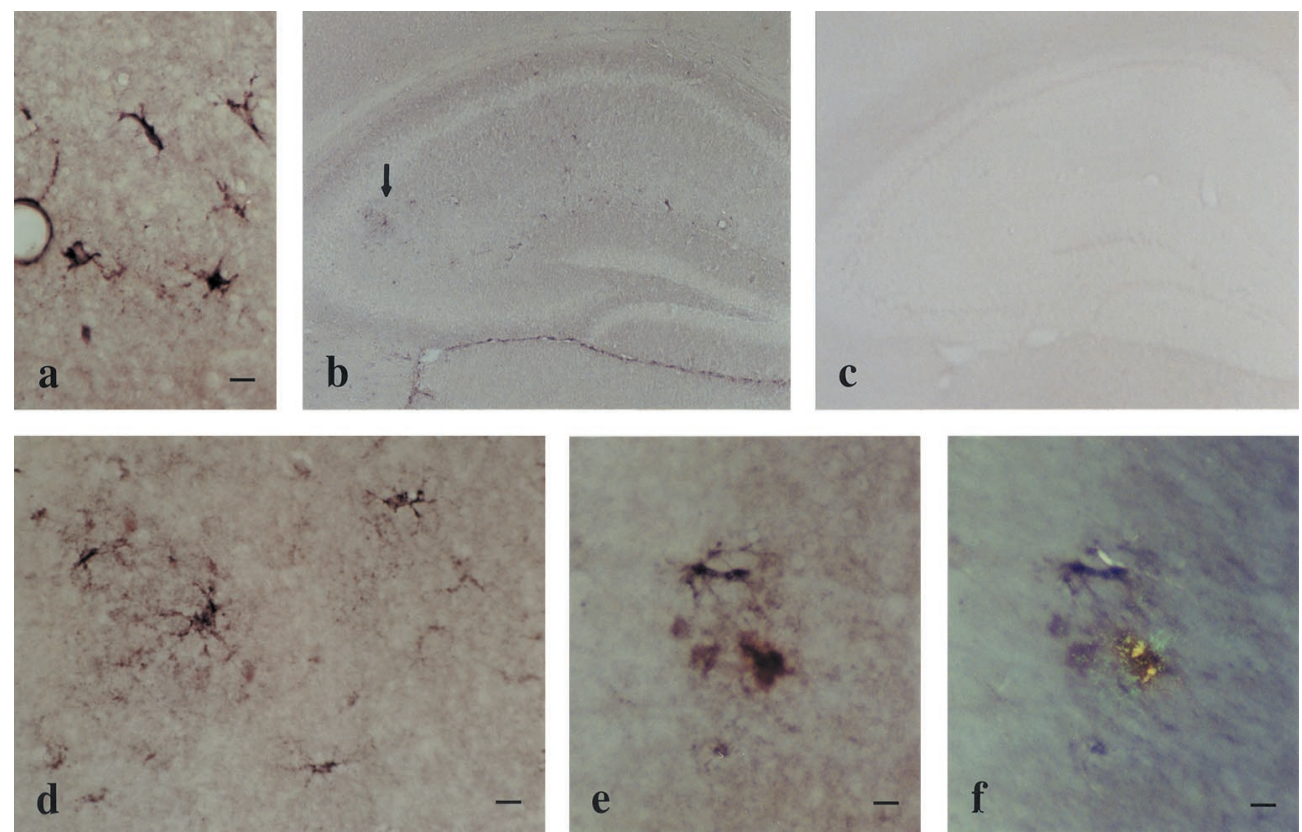

ACT-immunostained astrocytes were more widespread and often located around Congo Red birefringent plaques in the PDGFhAPP/V717F (+/-) ACT(+/-) mice (Fig. $2 b, d)$, but were absent in $\mathrm{PDGF}-\mathrm{hAPP} / \mathrm{V} 717 \mathrm{~F}(+/-) \mathrm{ACT}(-/-)$ mice of the same age (Fig. 2c). Furthermore, polyclonal ACT antibody not only stained the surrounding astrocytes but also Congo Red birefringent plaques, as depicted in the hippocampus of a 10-month-old $\operatorname{PDGF}-\mathrm{hAPP}(+/-) \mathrm{ACT}(+/-)$ mouse (Fig. 2e,f).

\section{Higher amyloid plaque load and frequency in APP/ACT transgenic mice}

Amyloid burden, as measured by Congo Red staining, was quantified using high-power microscopy and image analysis in 10month-old PDGF-hAPP/V717F $(+/-) \operatorname{ACT}(+/-)(n=7)$ and PDGF-hAPP/V717F $(+/-)$ ACT $(-/-)(n=6)$ animals. Amyloid burden (area fraction) was significantly increased in the hippocampus $(0.0136 \pm 0.0019$ vs $0.0088 \pm 0.0008 \%$; $+55 \% ; p<$ $0.05)$ and modestly increased in the cerebral cortex $(0.0155 \pm$ 0.0038 vs $0.0136 \pm 0.0012 \%$; $+14 \%$; NS) of the PDGF-hAPP/ $\mathrm{V} 717 \mathrm{~F}(+/-) \mathrm{ACT}(+/-)$ animals compared with the PDGFhAPP/V717F (+/-)ACT(-/-) animals (Fig. 3a). The increased amyloid burden was largely attributable to an increased numerical density of Congo Red-positive plaques both in the hippocampus $(+85 \% ; p<0.05)$ and the cerebral cortex $(+58 \% ; p<0.05$; Fig. $3 b)$. The plaque density data were then stratified according to plaque size (Fig. 4). The increased numerical density was most pronounced among small size plaques $\left(<50 \mu \mathrm{m}^{2}\right)$ both in the hippocampus $(+170 \% ; p<0.05$; Fig. $4 a)$ and the cerebral cortex $(+85 \% ; p<0.05$; Fig. $4 b)$. The density of larger plaques $(>50$ $\left.\mu \mathrm{m}^{2}\right)$ was also increased, but to a lower extent $(+43 \%$ in the hippocampus, $+39 \%$ in the cerebral cortex) that was not statistically significant.

The plaque size distribution was more completely analyzed using relative frequency histograms. We found that the linear histograms were substantially skewed to the right (data not shown) and that a logarithmic transformation of the plaque size data generated a very good fit of the sizes of the Congo Redpositive plaques to a Gaussian distribution (Fig. $4 c, d$ ). The correlation coefficient was $\geq 0.94$ for all analyses when using a Gauss-
Figure 2. Astrocyte-specific expression and plaque association of ACT protein in double APP/ACT transgenic mice. $a$, Astrogliotic ACT immunostaining along the hippocampal fissure in 6-month-old mouse. $b$, ACT-immunopositive astrocytes were present in a 10 -month-old PDGF-hAPP/V717F(+/-)ACT (+/-) mouse $(c)$ but absent in a 10-month-old PDGF-hAPP/V717F (+/-)ACT $(-/-)$ mouse. $d$, High-power magnification of ACT-immunopositive astrocytes close to Congo Red-positive amyloid plaques in a hippocampal subregion marked by an $a r-$ row in b.e, High-power magnification of an ACT-immunopositive Congo Redpositive amyloid plaque in the hippocampus of a PDGF-hAPP/V717F $(+/-)$ $\operatorname{ACT}(+/-)$ mouse at 10 months of age $(f)$ displaying birefringence under polarized light. Scale bars: $a, e, f, 7.8 \mu \mathrm{m} ; d$, $12.5 \mu \mathrm{m}$.
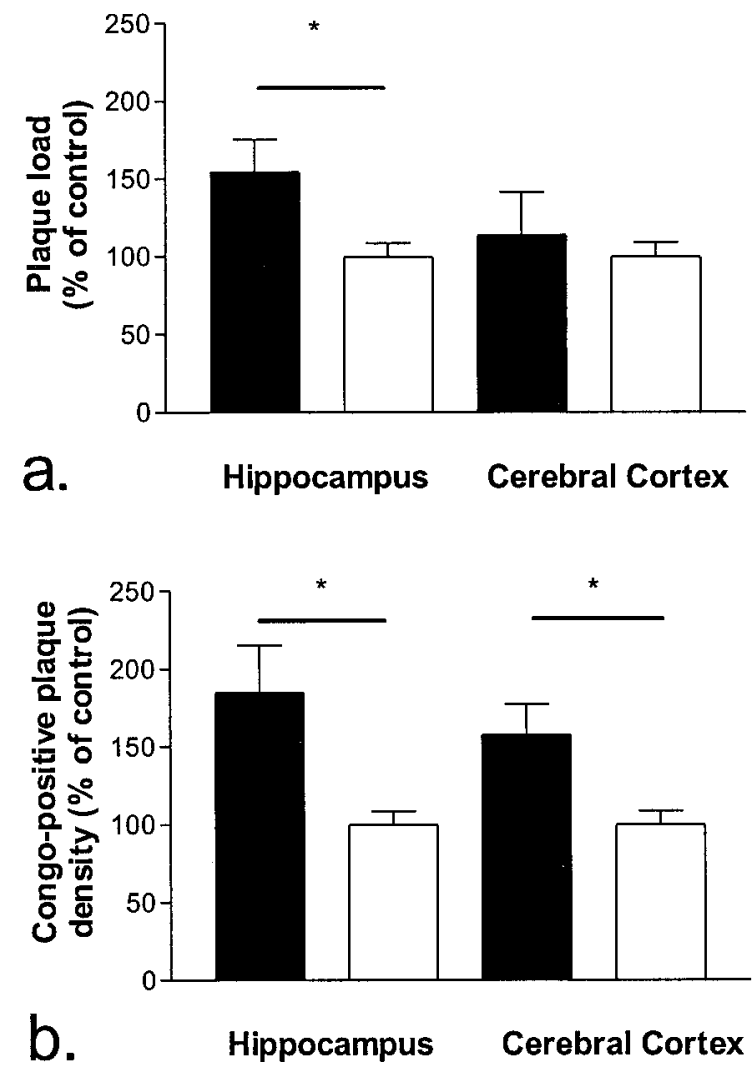

Figure 3. Increased total Congo Red-positive amyloid plaque load ( $a$ ) and numerical plaque density $(b)$ in the hippocampus and the cerebral cortex of 10-month-old PDGF-hAPP/V717F $(+/-)$ ACT $(+/-)$ mice $(n=$ 7; solid bar), compared with age-matched PDGF-hAPP/V717F $(+/-) \operatorname{ACT}(-/-)$ mice $(n=6$; open bar $)$. The results are expressed as percentage of the control group (the PDGF-hAPP/V717F $(+/-) \mathrm{ACT}(-/-)$ genotype mice) and represent mean \pm SEM.

ian distribution equation for the nonlinear regression analysis. This approach has been shown to successfully describe the senile plaque size distribution in human AD brain (Hyman et al., 1995). 
Figure 4. Plaque density analysis. Congopositive amyloid plaques in the hippocampus ( $a$, $c)$ and the cerebral cortex $(b, d)$ were stratified according to their sizes. There was an increased numerical density of small plaques $\left(<50 \mu \mathrm{m}^{2}\right)$ in the 10-month-old PDGF-hAPP/V717F $(+/-)$ $\mathrm{ACT}(+/-)$ mice $(n=7$; solid bar) compared with the age-matched PDGF-hAPP/V717F $(+/-)$ $\operatorname{ACT}(-/-)$ mice $(n=6$; open bar $)$ in the hippocampus $(a)$ and cerebral cortex $(b)$. Shown below bar graphs are the corresponding relative frequency histograms of plaque size distribution in mice of the PDGF-hAPP/V717F $(+/-)$ ACT $(+/-)$ (solid bar) and the PDGF-hAPP/ $\mathrm{V} 717 \mathrm{~F}(+/-), \mathrm{ACT}(-/-)$ genotypes (hatched bar) in the hippocampus $(c)$ and the cerebral cortex $(d)$. Superimposed is the best fit of our data to a Gaussian distribution for mice of the PDGF$\mathrm{hAPP} / \mathrm{V} 717 \mathrm{~F}(+/-) \mathrm{ACT}(+/-)$ (solid line) and the PDGF-hAPP/V717F (+/-) ACT(-/-) genotypes (broken line). The center of the Gaussian distribution curve for the PDGF-hAPP/V717F(+/ $-) \mathrm{ACT}(+/-)$ mice was shifted toward a smaller average plaque size in the hippocampus $(c)$ as well as the cerebral cortex $(d)$. The results displayed are expressed as percentage of the control group [the PDGF-hAPP/V717F(+/-)ACT $(-/-)]$ genotype and represent mean \pm SEM.
Hippocampus

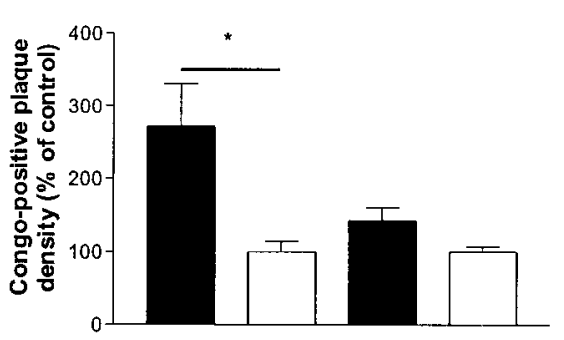

a.
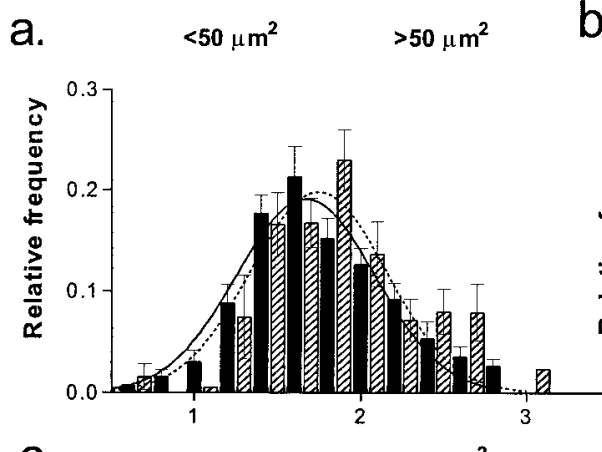

C.
Cerebral Cortex

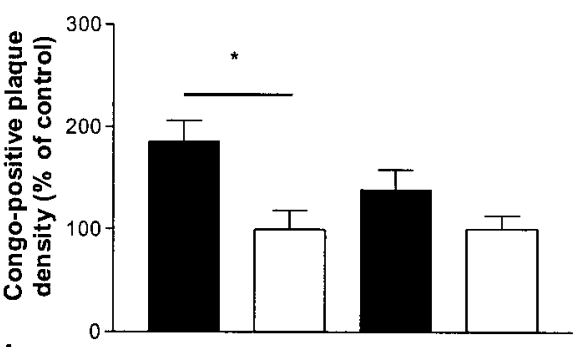

b.

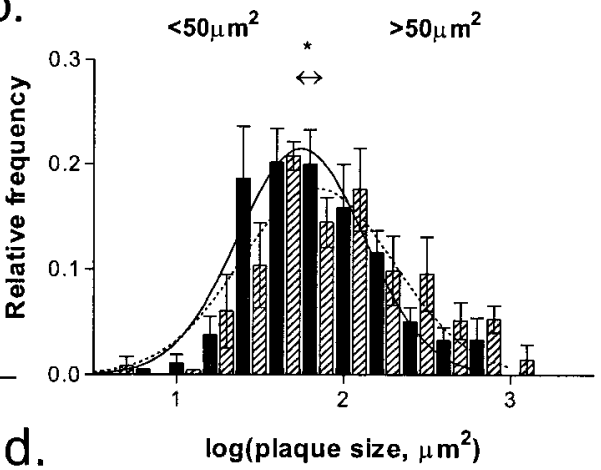

The center of the Gaussian distribution curve for the PDGFhAPP/V717F(+/-)ACT(+/-) mice was significantly shifted toward a smaller average plaque size in the cerebral cortex $(56 \pm 3$ vs $70 \pm 7 \mu \mathrm{m}^{2} ; p<0.05$; Fig. $4 d$ ) compared with PDGF-hAPP/ $\mathrm{V} 717 \mathrm{~F}(+/-) \mathrm{ACT}(-/-)$ mice, and a similar not statistically significant trend was apparent in the hippocampus (47 \pm 3 vs $56 \pm$ $5 \mu \mathrm{m}^{2} ; p<0.1$; Fig. $\left.4 c\right)$.

\section{Increased amyloid $\beta$-peptide levels in young APP/ACT transgenic mice}

Amyloid $\beta$-peptides levels in the hippocampus of 3-month-old mice were examined to determine whether ACT influenced amyloid $\beta$-peptide metabolism. There was a significant increase in total amyloid $\beta$-peptide levels $(0.55 \pm 0.05$ vs $0.43 \pm 0.03 \mathrm{ng} / \mathrm{mg}$ protein; $+27 \% p<0.05 ; n=10$ and $n=14$, respectively) in the hippocampus of 3-month-old PDGF-hAPP/V717F(+/-)ACT(+/-) mice compared with age-matched PDGF-hAPP/V717F $(+/-) \mathrm{ACT}$ $(-/-)$ mice. In addition, a similar not statistically significant trend toward increased hippocampal amyloid $\beta$-peptide(1-42) levels in the PDGF-hAPP/V717F $(+/-) \mathrm{ACT}(+/-)$ mice compared with age-matched PDGF-hAPP/V717F $(+/-) \mathrm{ACT}(-/-)$ mice was apparent $(0.11 \pm 0.01$ vs $0.09 \pm 0.01 \mathrm{ng} / \mathrm{mg}$ protein; $+22 \% ; p<0.1$; Fig. 5). However, the amyloid $\beta$-peptide(1-42)/total amyloid $\beta$-peptide ratio was identical $(0.21 \pm 0.01$ vs $0.21 \pm 0.01)$.

\section{DISCUSSION}

In the present transgenic mouse model, we have been able to reproduce several of the previous findings with respect to ACT expression in normal and Alzheimer's disease-afflicted human brain. Specifically, basal ACT expression in human brain is very low (Abraham et al., 1988), as is the expression in the transgenic mice at an early age before amyloid deposition. The singly ACT transgenic mice express fully glycosylated ACT protein $(\sim 68$ $\mathrm{kDa}$ ) that closely comigrates with human plasma ACT protein. We cannot exclude a subtle size difference between mouse brain and human plasma ACT because of the extent of glycosylation. Indeed human liver ACT $(66-75 \mathrm{kDa})$, the source of human

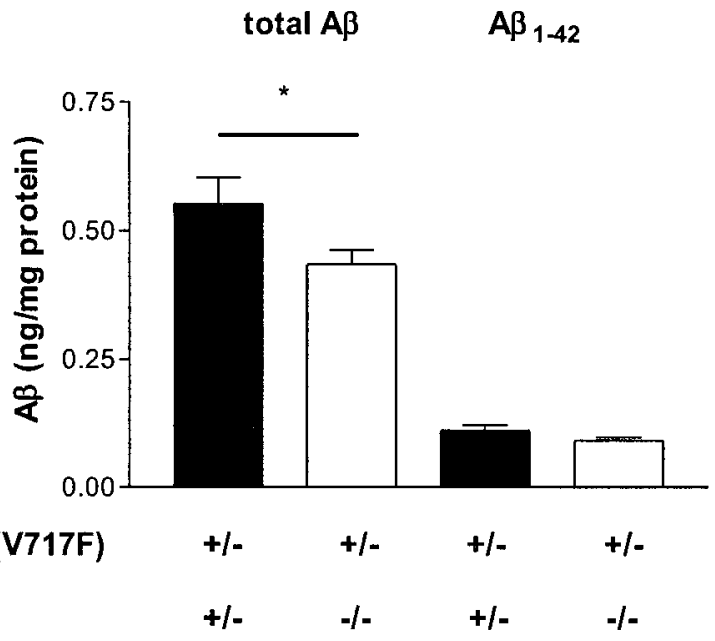

Figure 5. Increased total amyloid $\beta$-peptide $(\mathrm{A} \beta)$ and $\mathrm{A} \beta_{1-42}$ levels in the hippocampus of 3-month-old PDGF-hAPP/V717F $(+/-) \mathrm{ACT}(+/-)$ mice $(n=10$; solid bar) compared with age-matched PDGF hAPP/ $\mathrm{V} 717 \mathrm{~F}(+/-) \mathrm{ACT}(-/-)$ mice $(n=14$; open bar $)$.

plasma ACT, and hippocampal ACT (60-65 kDa) differ slightly in molecular size (Hwang et al., 1999). The basal expression of transgene ACT in singly ACT transgenic mice as well as in crossed APP/ACT transgenic mice is restricted to astrocytes in white matter areas and close to the ventricles. These findings are consistent with strong GFAP immunostaining of white matter astrocytes in nontransgenic mice, as well as the distribution of ACT-immunostained astrocytes in human brain without pathological changes (Abraham et al., 1988; Pasternack et al., 1989; Koo et al., 1991). The ACT immunostaining of astrocyte processes likely represents intracellular ACT that is about to be secreted as well as extracellular ACT in the immediate vicinity of the astrocyte processes. Immunostaining of astrocyte processes of the secretory chaperone protein ApoE has previously been 
SPORADIC OR FAMILIAL ALZHEIMER'S DISEASE
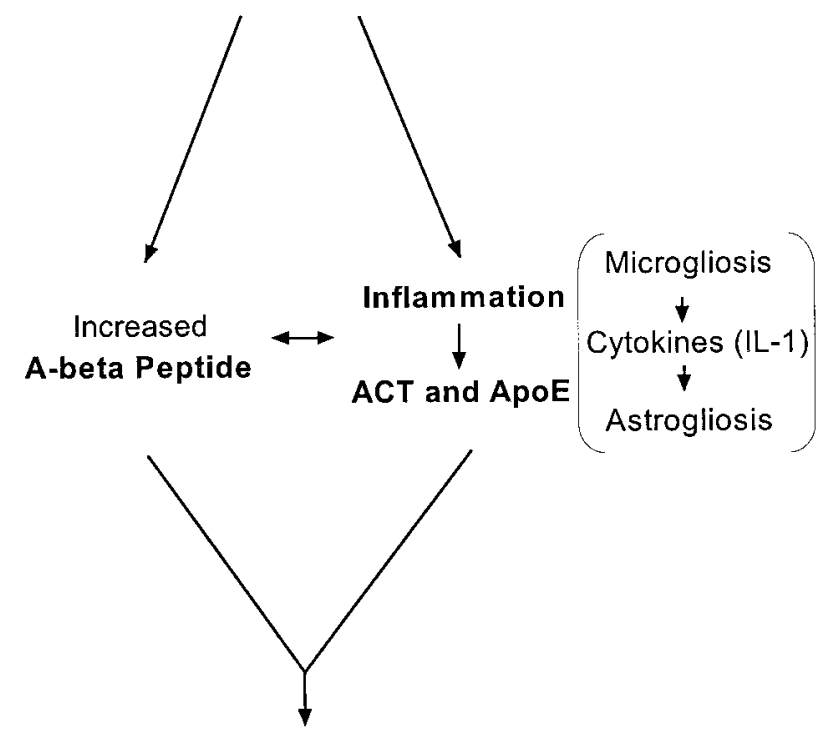

Amyloid Filaments

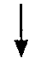

Neurotoxicity

Figure 6. Pathogenic pathway leading to Alzheimer's disease.

described after GFAP promoter-driven transgene expression (Sun et al., 1998).

As the amyloid formation proceeds, the astrocytic ACT expression gradually increases, primarily in the hippocampus but also in the cerebral cortex of the PDGF-hAPP/V717F $(+/-) \mathrm{ACT}(+/-)$ transgenic mice. ACT also becomes a constituent of the Congo Red-positive amyloid plaque structure itself, similar to previous observations in AD brain (Abraham et al., 1988). Most importantly there is an increased amyloid burden in 10-month-old PDGF-hAPP/V717F (+/-)ACT(+/-) mice compared with PDGF-hAPP/V717F(+/-)ACT(-/-) mice, particularly in the hippocampal formation where ACT expression in astrocytes is observed early on as the amyloidosis develops. We suggest that the stronger amyloid-promoting effect of ACT in the hippocampus, compared with the cerebral cortex, is attributable to the more extensive astrogliotic reaction and GFAP induction in the hippocampus, which in turn will lead to the secretion of higher concentrations of transgene ACT in the hippocampus.

These findings suggest that the ACT protein not only becomes synthesized and secreted as a secondary response to ongoing cerebral amyloidosis, but also further promotes amyloid deposition and formation of the $\beta$-sheet structure of mature plaques, likely by a direct molecular interaction with $\mathrm{A} \beta$. This increased amyloid formation caused by ACT is over and above that attributable to endogenous ApoE expression, which is present in all of the mice analyzed. Furthermore, because the increased amyloid burden was largely attributable to increased plaque density, it is likely that ACT either initiates amyloid filament formation or catalyzes other early amyloid filament processes by interacting with $\mathrm{A} \beta$ peptides or intermediate oligomeric $\mathrm{A} \beta$ structures. The more numerous Congo Red-positive plaques were also of a smaller size in the ACT-expressing mice, again consistent with $\mathrm{ACT}$ functioning at an early, rate-limiting step in plaque development, but also with ACT either retarding further growth of plaques or altering their structure so that they become more dense. The increased plaque density, the shift in senile plaque size distribution, and the ACT-immunopositive staining of Congo Red-positive plaques together strongly suggest that ACT is directly involved in amyloid plaque formation at the molecular level, likely by promoting filament formation. It is possible that the amyloid-promoting effect by ACT would have been less with the weaker human ACT promoter. The choice of GFAP as a surrogate promoter was based on previous findings that ACTmRNA and GFAP-mRNA expression correlate well in both healthy and human brain tissue afflicted by various neuropathological conditions (Koo et al., 1991). It was also unclear whether the human ACT promoter would have been functional in mouse brain astrocytes with respect to cytokine responsiveness and therefore might not have responded to astrogliosis (Das and Potter, 1995).

Finally, the increased steady-state levels of amyloid $\beta$-peptide observed in the brains of 3-month-old ACT-expressing mice before amyloid deposition might also contribute to the increase in amyloid deposition observed in the animals at 10 months of age. We suggest that the increased steady state levels of $A \beta$ in the hippocampus are caused either by $\mathrm{ACT} / \mathrm{A} \beta$ peptide complex formation, which will tend to unspecifically retard $\mathrm{A} \beta$ peptide clearance in the extracellular space, or by inhibition of a specific amyloid $\beta$-peptide degrading enzyme by $\mathrm{ACT}$, as previous in vitro studies have suggested (Yamin et al., 1999).

Our findings provide further evidence that amyloid-associated proteins, induced by inflammatory cytokines, act as pathological chaperones and play an essential role in the AD disease pathogenesis (for review, see Nilsson et al., 1998; Wisniewski et al., 1998; Bales et al., 2000). The results also suggest that ACT may exert an effect on APP processing or more likely $\mathrm{A} \beta$ peptide clearance.

The overexpression of ACT in astrocytes and of interleukin-1 (IL-1) in microglia in regions of AD brain with frequent densecore senile plaques first suggested that these inflammatory proteins might be involved in senile plaque formation or maturation (Abraham et al., 1988; Griffin et al., 1989; Das and Potter, 1995; Sheng et al., 1995). IL-1 is a powerful inducer of APP-mRNA translation (Rogers et al., 1999) as well as ACT-mRNA expression (Das and Potter, 1995) in primary human astrocytes, and glial activation is accompanied by increased expression of ApoE both in vitro and in AD brain (Diedrich et al., 1991; Bales et al., 2000). Indeed, the finding of pronounced astrogliosis and microgliosis in PDGF-hAPP/V717F $(+/-) \operatorname{ApoE}(-/-)$ mice in the absence of $\beta$-pleated sheet amyloid formation (Bales et al., 1999) suggests that the importance of gliosis with respect to amyloid formation in $\mathrm{AD}$ is that it leads to the production and release of specific amyloid-promoting factors, such as ACT and ApoE.

Additional support for the involvement of an inflammatory cascade leading to increased amyloid formation comes from the discovery of polymorphisms that confer increased risk of developing AD or amyloid angiopathy. Such polymorphisms have been identified in the IL-1 promoter (Du et al., 2000; Grimaldi et al., 2000; Nicoll et al., 2000), the ACT (Kamboh et al., 1995; Yamada et al., 1998), and the ApoE coding regions (Corder et al., 1993; Strittmatter et al., 1993) as well as the ApoE promoter (Bullido et al., 1998).

In light of the current findings, it is interesting and important 
that retrospective, and more recently, prospective pharmacoepidemiological studies on certain populations have concluded that inflammation plays a role in AD (McGeer et al., 1990; for review, see Nilsson et al., 1998; Akiyama et al., 2000). Together with these results, our data support the hypothesis that specific inflammatory processes accelerate the progression of $\mathrm{AD}$ as a part of a "pathogenic pathway" (Fig. 6). Each step in the pathway discussed here-for example the overexpression and release of IL-1 in microglial cells, the induction of ACT-mRNA expression in astrocytes, and the molecular interactions between ACT (and ApoE) and $\mathrm{A} \beta$ peptides and aggregates to promote amyloid formation-constitutes a specific therapeutic target at which new AD drug discovery may be directed.

Note added in proof. While this paper was being reviewed, Mucke et al. (2000) published a related study using hACT transgenic mice that had been created using a different GFAP-hACT expression vector construct. The authors showed, similar to our findings, that hACT increased amyloid deposition in the PDGF-hAPP/V717F transgenic mice.

\section{REFERENCES}

Abraham CR, Selkoe DJ, Pottter H (1988) Immunohistochemical identification of the serine protease inhibitor $\alpha_{1}$-antichymotrypsin in the brain amyloid deposits of Alzheimer's disease. Cell 52:487-501.

Abraham CR, Shirahama T, Potter H (1990) $\alpha_{1}$-antichymotrypsin is associated solely with amyloid deposits containing the $\beta$-protein. Amyloid and cell localization of $\alpha_{1}$-antichymotrypsin. Neurobiol Aging 11:123-129.

Akiyama H, Barger S, Barnum S, Bradt B, Bauer J, Cole GM, Cooper NR, Eikelenboom P, Emmerling M, Fiebich BL, Finch CE, Frautschy S, Griffin WS, Hampel H, Hull M, Landreth G, Lue L, Mrak R, Mackenzie IR, McGeer PL, O’Banion MK, Pachter J, Pasinetti G, Plata-Salaman C, Rogers J, Rydel R, Shen Y, Streit W, Strohmeyer R, Tooyoma I, Van Muiswinkel FL, Veerhuis R, Walker D, Webster S, Wegrzyniak B, Wenk G, Wyss-Coray T (2000) Inflammation and Alzheimer's disease. Neurobiol Aging 21:383-421.

Bales KR, Verina T, Dodel RC, Du Y, Altstiel L, Bender M, Hyslop P, Johnstone EM, Little SP, Cummins DJ, Piccardo P, Ghetti B, Paul SM (1997) Lack of apolipoprotein E dramatically reduces amyloid $\beta$-peptide deposition. Nat Genet 17:263-264.

Bales KR, Verina T, Cummins DJ, Du Y, Dodel RC, Saura J, Fishman CE, Delong CA, Piccardo P, Petegnief V, Ghetti B, Paul SM (1999) Apolipoprotein E is essential for amyloid deposition in the APP V717F transgenic mouse model of Alzheimer's disease. Proc Natl Acad Sci USA 96:15233-15238.

Bales KR, Du Y, Holtzman D, Cordell B, Paul SM (2000) Neuroinflammation and Alzheimer's disease: critical roles for cytokine/A $\beta$-induced glial activation, NF- $\kappa \mathrm{B}$, and apolipoprotein E. Neurobiol Aging 21:427-432.

Bullido MJ, Artiga MJ, Rcuero M, Sastre I, Garcia MA, Aldudo J, Lendon C, Han SW, Morris JC, Frank A, Vazquez J, Goate A, Valdivieso F (1998) A polymorphism in the regulatory region of ApoE associated with risk for Alzheimer's dementia. Nat Genet 18:69-71.

Corder EH, Saunders AM, Strittmatter WJ, Schmechel DE, Gaskell PC, Small GW, Roses AD, Haines JL, Pericak-Vance MA (1993) Gene dose of apolipoprotein E type 4 allele and the risk of Alzheimer's disease in late onset families. Science 261:921-923.

Das S, Potter H (1995) Expression of the Alzheimer amyloid-promoting factor antichymotrypsin is induced in human astrocytes by IL-1. Neuron 14:447-456.

Diedrich JF, Minnigan H, Carp RI, Whitaker JN, Race R, Frey II W, Haase AT (1991) Neuropathological changes in scrapie and Alzheimer's disease are associated with increased expression of apolipoprotein E and cathepsin D in astrocytes. J Virol 65:4759-4768.

Du Y, Dodel RC, Eastwood BJ, Bales KR, Gao F, Lohmüller F, Müller U, Kurz A, Zimmer R, Evans RM, Hake A, Gasser T, Oertel WH, Griffin WS, Paul SM, Farlow MR (2000) Association of an interleukin 1 alpha polymorphism with Alzheimer's disease. Neurology 55:480-484

Eriksson S, Janciauskiene S, Lannfelt L (1995) $\alpha_{1}$-antichymotrypsin regulates Alzheimer $\beta$-amyloid peptide fibril formation. Proc Natl Acad Sci USA 92:2313-2317.

Evans KC, Berger EP, Cho C-G, Weisgraber KH, Lansbury Jr PT (1995) Apolipoprotein $\mathrm{E}$ is a kinetic but not a thermodynamic inhibitor of amyloid formation: implications for the pathogenesis and treatment of Alzheimer's disease. Proc Natl Acad Sci USA 92:763-767.

Franklin KBJ, Paxinos G (1996) The mouse brain in stereotaxic coordinates. New York: Academic.
Fraser PE, Nguyen JT, McLachlan DR, Abraham CR, Kirschner DA (1993) $\alpha_{1}$-antichymotrypsin binding to Alzheimer $\mathrm{A} \beta$ peptides is sequence specific and induces fibril disaggregation in vitro. J Neurochem 61:298-305.

Games D, Adams D, Alessandrini R, Barbour R, Berthelette P, Blackwell C, Carr T, Clemes J, Donaldson T, Gillespie F, Guido T, Hagopian S, Johnson-Wood K, Khan K, Lee M, Leibowitz P, Lieberburg I, Little S, Masliah E, McConlogue L, Montoya-Zavala M, Mucke L, Paganini L, Penniman E, Power M, Schenk D, Seubert P, Snyder B, Soriano F, Tan H, Vitale J, Wadsworth S, Wolozin B, Zhao J (1995) Alzheimer-type neuropathology in transgenic mice overexpressing V717F $\beta$-amyloid precursor protein. Nature 373:523-527.

Griffin WST, Stanley LC, Ling C, White L, Macleod V, Perrot LJ, White III CL, Araoz C (1989) Brain interleukin-1 and S-100 immunoreactivity are elevated in Down syndrome and Alzheimer disease. Proc Natl Acad Sci USA 86:7611-7615.

Grimaldi LME, Casadei VM, Ferri C, Veglia F, Licastro F, Annoni G, Biunno I, De Bellis G, Sorbi S, Mariani C, Canal N, Griffin WST, Franceschi M (2000) Association of early-onset Alzheimer's disease with an Interleukin-1 $\alpha$ gene polymorphism. Ann Neurol 47:361-365.

Hill RE, Hastie ND (1987) Accelerated evolution in the reactive centre regions of serine protease inhibitors. Nature 326:96-99.

Holzman DM, Bales KR, Tenkova T, Fagan AM, Parsadanian M, Sartorius LJ, Makey B, Olney J, McKeel D, Wozniak D, Paul SM (2000) Apolipoprotein $\mathrm{E}$ isoform-dependent amyloid deposition and neuritic degeneration in a mouse model of Alzheimer's disease. Proc Natl Acad Sci USA 97:2892-2897.

Hughes SR, Khorkova O, Goyal S, Knaeblein, Heroux J, Riedel NG, Saharabudhe S (1998) $\alpha_{2}$-macroglobulin associates with $\beta$-amyloid peptide and prevents fibril formation. Proc Natl Acad Sci USA 95:3275-3280.

Hwang S-R, Steineckert B, Kohn A, Palkovits M, Hook VYH (1999) Molecular studies define the primary structure of $\alpha_{1}$-antichymotrypsin (ACT) protease inhibitor in Alzheimer's disease brain. J Biol Chem 274:1821-1827.

Hyman BT, West HL, Rebeck GW, Buldyrev SV, Mantegna RN, Ukleja M, Havlin S, Stanley HE (1995) Quantitative analysis of senile plaques in Alzheimer disease: observation of log-normal size distribution and molecular epidemiology of differences associated with apolipoprotein E genotype and trisomy 21 (Down syndrome). Proc Natl Acad Sci USA 92:3586-3590.

Inglis JD, Hill RE (1991) The murine Spi-2 proteinase inhibitor locus: a multigene family with a hypervariable reactive site domain. EMBO J $10: 255-261$

Janciauskiene S, Eriksson S, Wright HT (1996) A specific structural interaction of Alzheimer's peptide $\mathrm{A} \beta_{1-42}$ with $\alpha_{1}$-antichymotrypsin. Nat Struct Biol 3:668-671.

Janciauskiene S, Rubin H, Lukacs CM, Wright HT (1998) Alzheimer's peptide $A \beta_{1-42}$ binds to two $\beta$-sheets of $\alpha_{1}$-antichymotrypsin and transforms it from an inhibitor to substrate. J Biol Chem 273:28360-28364.

Kamboh MI, Sanghera DK, Ferrell RE, DeKosky ST (1995) ApoE4associated Alzheimer's disease risk is modified by $\alpha_{1}$-antichymotrypsin polymorphism. Nat Genet 10:486-488.

Koo EH, Abraham CR, Potter H, Cork LC, Price DL (1991) Developmental expression of $\alpha_{1}$-antichymotrypsin in brain may be related to astrogliosis. Neurobiol Aging 12:495-501.

Ma J, Yee A, Brewer Jr HB, Das S, Potter H (1994) Amyloid-associated proteins $\alpha_{1}$-antichymotrypsin and apolipoprotein $\mathrm{E}$ promote assembly of Alzheimer $\beta$-protein into filaments. Nature 372:92-94.

Ma J, Brewer Jr HB, Potter H (1996) Alzheimer A beta neurotoxicity: promotion by antichymotrypsin. ApoE4; inhibition by A beta-related peptides. Neurobiol Aging 17:773-780.

McGeer PL, McGeer E, Rogers J, Sibley J (1990) Anti-inflammatory drugs and Alzheimer disease. Lancet 335:1037.

Mucke L, Yu G-Q, McConlogue L, Rockenstein EM, Abraham CR, Masliah E (2000) Astroglial expression of human $\alpha_{1}$-antichymotrypsin enhances Alzheimer-like pathology in amyloid protein precursor transgenic mice. Am J Pathol 157:2003-2010.

Nakatani Y, Brenner M, Freese E (1990) An RNA polymerase II promoter containing sequences upstream and downstream from the RNA startpoint that direct initiation of transcription from the same site. Proc Natl Acad Sci USA 87:4289-4293.

Nicoll JAR, Mrak RE, Graham DI, Stewart J, Wilcock G, MacGowan S, Esiri MM, Murray LS, Dewar D, Love S, Moss T, Griffin WST (2000) Association of interleukin-1 gene polymorphisms with Alzheimer's disease. Ann Neurol 47:365-368.

Nilsson L, Rogers J, Potter H (1998) The essential role of inflammation and induced gene expression in the pathogenic pathway of Alzheimer's disease. Front Biosci 16:436-446.

Pasternack JM, Abraham CR, Van Dyke BJ, Potter H, Younkin SG (1989) Astrocytes in Alzheimer's disease gray matter express alpha1antichymotrypsin mRNA. Am J Pathol 135:827-834.

Potter H, Nelson RB, Das S, Siman R, Kayyali U,S, Dressler D (1992) The involvment of proteases, protease inhibitors, and an acute phase response in Alzheimer's disease. Ann NY Acad Sci 674:161-173. 
Rebeck GW, Reiter JS, Strickland DK, Hyman BT (1993) Apolipoprotein $\mathrm{E}$ in sporadic Alzheimer's disease: allelic variation and receptor interactions. Neuron 11:575-580.

Rogers JT, Leiter LM, McPhee J, Cahill CM, Zhan S-S, Potter H, Nilsson LNG (1999) Translation of the Alzheimer amyloid precursor protein mRNA is up-regulated by interleukin-1 through $5^{\prime}$-untranslated region sequences. J Biol Chem 274:6421-6431.

Sanan DA, Weisgraber KH, Russell SJ, Mahley RW, Huang D, Saunders A, Schmechel D, Wisniewski T, Frangione B, Roses AD, Strittmatter WJ (1994) Apolipoprotein E associates with beta amyloid peptide of Alzheimer's disease to form novel monofibrils. Isoform ApoE4 associates more efficiently than ApoE3. J Clin Invest 94:860-869.

Sarid J (1991) Identification of a cis-acting positive regulatory element of the glial fibrillary acidic protein gene. J Neurosci Res 28:217-228.

Schmechel DE, Saunders AM, Strittmatter WJ, Crain BJ, Hulette CM, Joo SH, Pericak-Vance MA, Goldgaber D, Roses AD (1993) Increased amyloid $\beta$-peptide deposition in cerebral cortex as a consequence of apolipoprotein E genotype in late-onset Alzheimer disease. Proc Natl Acad Sci USA 90:9649-9653.

Sheng JG, Mrak RE, Griffin WS (1995) Microglial interleukin-1 alpha expression in brain regions in Alzheimer's disease: correlation with neuritic plaque distribution. Neuropathol Appl Neurobiol 21:290-301. Strittmatter WJ, Weisgraber KH, Huang DY, Dong L-M, Salvesen GS,
Pericak-Vance M, Schmechel D, Saunders AM, Goldgaber D, Roses AD (1993) Binding of human apolipoprotein E to synthetic amyloid $\beta$ peptide: isoform-specific effects and implications for late-onset Alzheimer disease. Proc Natl Acad Sci USA 90:8098-8102.

Sun Y, Wu S, Bu G, Onifade MK, Patel SN, LaDu MJ, Fagan AM, Holtzman DM (1998) Glial fibrillary acidic protein-apolipoprotein E (ApoE) transgenic mice: astrocyte-specific expression and differing biological effects of astrocyte-secreted ApoE3 and ApoE4 lipoproteins. J Neurosci 18:3261-3272.

Wisniewski T, Frangione B (1992) Apolipoprotein E: a pathological chaperone protein in patients with cerebral and systemic amyloid. Neurosci Lett 135:235-238.

Wisniewski T, Castaño EM, Golabek A, Vogel T, Frangione B (1994) Acceleration of Alzheimer's fibril formation by apolipoprotein $\mathrm{E}$ in vitro. Am J Pathol 145:1030-1035.

Wisniewski T, Aucouturier P, Soto C, Frangione B (1998) The prionoses and other conformational disorders. Amyloid 5:212-224.

Yamada M, Sodeyama N, Itoh Y, Suematsu N, Otomo E, Matsushita M, Mizusawa H (1998) Association of the alpha1-antichymotrypsin polymorphism with cerebral amyloid angiopathy. Ann Neurol 44:129-131.

Yamin R, Malgeri EG, Sloane JA, McGraw WT, Abraham CR (1999) Metalloendopeptidase EC 3.4.24.15 is necessary for Alzheimer's amyloid-beta peptide degradation. J Biol Chem 274:18777-18784. 